Article

\title{
Immigrants and the City: The Relevance of Immigration on Housing Price Gradient
}

\author{
Valentina Antoniucci * (D) and Giuliano Marella \\ Department of Civil, Environmental and Architectural Engineering, University of Padova, Padua 35131, Italy; \\ giuliano.marella@unipd.it \\ * Correspondence: valentina.antoniucci@unipd.it; Tel.: +39-041-8276726
}

Received: 17 July 2017; Accepted: 12 October 2017; Published: 14 October 2017

\begin{abstract}
Foreign citizens are a more and more significant part of the population of Italian cities and society ( $8 \%$ of the country's total population), and they contribute to changes in the cultural, social, and economic structure of the country. Our aim was to assess the incidence of the immigrant population on urban house price polarization, as measured using an original indicator: the center-periphery housing price gradient. While there is ample literature on the relationship between average prices and immigrant populations, less research has been conducted on immigration and the housing price gradient on a national scale. This price gradient may indicate whether immigration contributes to changing the residential market, also possibly revealing segregation phenomena. We ran multivariate regressions in several steps on an original dataset of housing prices and socio-economic factors concerning 112 Italian provincial capitals to elucidate whether immigration is correlated with the housing market divide. Our main findings confirmed that larger immigrant populations coincide with steeper housing price gradients on a national scale. Our tests also demonstrated that the relevance of this phenomenon varies for different urban forms, confirming related to housing price dynamics between the cities of northern and southern Italy the relevance of urban density in elucidating.
\end{abstract}

Keywords: housing market; immigrants; multivariate regression; real estate market; price gradient

\section{Introduction}

The immigration phenomenon has been gaining in importance in Southern European economies, and particularly in Italy, where the influx of immigrants has risen in the last three years due to political instability in Northern Africa. This issue affects Greece and Spain too (as regards illegal arrivals), as well as Germany, France, and the UK (most immigrants' final destinations). Immigration has become one of the most urgent problems on the EU agenda, partly because of its effects on the economies of the Member States. According to the UN, Europe received 31.5\% of the world's migrants in 2015, more than Asia or the USA. According to Caritas and Migrantes [1], the most important Italian organizations dealing with immigration, the arrival in Europe of people from non-EU states has been growing since the economic crisis of 2008, but some countries-such as Greece (with 3.9\% fewer immigrants in 2015 than in the previous year) and Spain-have seen a decline in immigration since 2014 because their economic recessions have made these countries less attractive. Italy, on the other hand, saw $29 \%$ more immigrants arriving in 2015 than in the previous year. Foreign citizens living in Italy accounted for more than 5 million of the country's 60.6 million population in 2015, i.e., over $8 \%$ of the total (source: Italian National Statistics Institute, 2016). Most of these immigrants (almost 60\% in 2015) live concentrated in certain parts of the country. For instance, Lombardia in northern Italy alone accounts for $23 \%$ of the total, while the Campania region has $28.6 \%$ of the immigrant population in southern Italy, which is $15.2 \%$ of the total nationwide [1]. Immigration in Italy is a longstanding phenomenon: 
during the years 1990 to 2010, the country's immigrant population increased by a factor of 5 [2]; and this trend has persisted, albeit with less intensity, to the present day.

Foreign citizens thus make up a more and more significant part of the population of Italian cities and society. This situation has two facets. For a start, the stable trend of the immigration flows means a growing influence of foreign populations on how our cities are changing. There has been an increase in segregation phenomena, but foreigners' economic activities and customs are also modifying the face of these cities. Second, the role of the immigrant population is also growing because of the ongoing decline in the birth rate and the rising average age of the autochthonous population. For cultural reasons, and because of the crisis in the country's welfare system, the Italian birth rate now relies heavily on the immigrants' contribution. This means that the economic relevance of foreign citizens living and working in Italy is bound to increase. For the time being, immigrants contribute for around $10 \%$ of the country's GDP (Source: ISTAT, Italian Institute of Statistics), but the immigrant population is also more vulnerable to urban poverty and social deprivation in a fragile economy like Italy's. Their presence can consequently have a crucial influence on urban policies.

Town planners have begun to study how cities are changed by the settlement of foreign citizens [3], and labor economics focuses on their influence on the labor market $[4,5]$. But real estate economics, especially in Europe, has yet to thoroughly analyze how the property market-and the housing market in particular-changes as a result of immigrants making up a growing proportion of the resident population.

The literature has focused mainly on rising average housing prices driven by the demand side due to a rapid growth in urban populations (see for instance [6-8]), and the fallout on the labor market in host countries $[9,10]$. We should presumably expect to see house prices increase in the cities more populated by immigrants. But does this apply to countries in periods of economic stagnation too? Or do the features of a country's immigration and a fragile economic framework make the housing market behave differently?

The aim of the present article was to examine whether the presence of immigrants correlates with the housing market divide between city center and the urban periphery. To address this issue, we used the housing price gradient between center and periphery rather than the average house prices, which can only reveal the polarization of prices between cities, not within them. In times of economic recession, especially in a country like Italy (which has one of the weakest economies of the Western Euro-Zone), it seems important to investigate whether a relationship exists between the immigrant population and urban polarization, also in terms of the housing market [11,12]. We investigated certain socio-economic factors to see whether immigration contributes to the housing market divide. We also aimed to ascertain whether housing price gradients vary for different degrees of urban density [13-15]. Although land theory explains the key factors influencing housing price gradients, the relevance of some socio-economic issues (including immigration) is contentous, and has not been thoroughly investigated.

Our main findings confirmed that larger immigrant populations coincide with steeper housing price gradients on a national scale in Italy. Our tests also demonstrated that the size of this phenomenon varies for different urban forms, reflecting significant differences in the urban structure of cities in northern and southern Italy.

This study contributes to the existing literature in three ways. First, it extends the findings of recent studies on the effects of immigration on house prices in Southern Europe. Apart from a few noteworthy examples $[16,17]$, this socio-economic issue has been poorly analyzed in Europe, and especially in Italy. Second, it describes an original application of the housing price gradient to address the relationship between foreign citizens and price polarization, which may provide an indication of social polarization within cities. Third, it may help to predict how Italian cities will grow differently under the variable effects of immigration on the demand side of the housing market.

The rest of the article is organized as follows: Section 2 presents a review of the relevant literature; Section 3 describes the data and the model used to assess the relationship between immigration and 
housing prices; Section 4 presents and discusses the results obtained; and, Section 5 concludes with some policy implications and suggestions for further research.

\section{Literature Review}

\subsection{Housing Prices and Immigration}

The most innovative studies on the consequences of immigration follow two different strands, developed mostly in the US: (i) immigrants and spatial segregation; and (ii) immigrants and housing demand. Considerable attention has been devoted to immigrants' spatial segregation in relation to housing markets, and to the impact of internal mobility and the choices of location made by natives faced with the local clustering of immigrant populations. The tendency of immigrants to cluster in certain cities and neighborhoods seems to drive the natives elsewhere-even in Italy, where the proportion of the immigrant population is still relatively small $[5,18,19]$.

There is an abundance of literature on the spatial segregation deriving from immigrants' tendency to reside where their ethnic group is more concentrated, which improves their chances of sharing knowledge, job opportunities, and customs [20]. Spatial segregation also correlates strongly with less skilled jobs and lower wages, however [21,22]. The issue has also been analyzed in terms of whether public action can promote or contain the phenomenon [23,24]. Town planners and urban researchers have discussed how the structure of a city may influence spatial inequality, with largely conflicting results. While the theorists of neoclassical liberalism disregard urban form-and urban density versus sprawl in particular-as a possible cause of racial or ethnic segregation [8,25], other scholars see sprawl as a driver of inequality and segregation in metropolitan areas. Given the strong reliance on private transportation and the limited public transport services in sprawling metropolitan areas, many Western US city centers are characterized by income and racial segregation (see [26,27], among others).

Foreign-born resident clustering is strongly associated with local housing market trends. As in the labor market, Saiz [28] estimated that a $1 \%$ increase in median rents and housing prices in US "gateway" cities was associated with a $1 \%$ immigration inflow into a city's population. Saiz ([28] p. 346) found "a very robust impact on rents and housing prices that is an order of magnitude bigger than the estimates from wages literature". This kind of empirical analysis has been performed not only in the US, but also in Canada [29] and Russia [30].

As for Europe, empirical studies on the impact of immigration on housing prices are scarce. Gonzales and Ortega [17] said that rising immigration during the years 2000-2010 contributed to the housing market boom in Spain. They estimated an annual $2 \%$ increase in housing prices, and a $1.2-1.5 \%$ increase in housing units. Degan \& Fisher [31] likewise found a 2.7\% growth in housing prices correlating with a $1 \%$ growth in the immigrant population in Switzerland, despite a flat market and a low level of immigration. Sà [32], on the other hand, identified a negative correlation between immigration and housing prices due to the previously-mentioned mobility of the native population.

Accetturo et. al. [4] conducted one of the few empirical studies on Italian cities, finding that "housing price growth in a district affected by immigration is lower in relation to the city average" ([4], p. 49), even during a housing boom. Using a dataset on 20 Italian cities, they calculated a $2 \%$ fall in prices for every $10 \%$ increase in immigrant stock at the district level, by comparison with the rest of the city. Their work thus demonstrated the negative correlation between high proportions of immigrants in the population and the natives' choice of location at neighbourhood level. As Mussa et al. [33] said "The idea that natives may move out when immigrants move in and that home prices and rental rates may be differentiated by the timing of immigration, points out the importance of accounting for the geography of immigration". On these grounds, our analysis covers cities across the whole of Italy, due to the different proportions of immigrants in the urban populations, from north to south, and from large cities to small towns. 


\subsection{The Housing Price Gradient: Theoretical Background and Related Socio-Economic Factors}

Housing prices vary significantly between and within cities. There has been an abundance of literature on the theoretical background for the housing price gradient, since the essential works by Alonso [34], Mills [35], and Muth [36]. Their studies focused on the effect of location on the prices of land, from the inner city to the fringe: access to infrastructure, job opportunities, and amenities increases the prices of central areas versus fringe areas. DiPasquale \& Wheaton [37], and Capozza et al. [38] subsequently further developed this theory, focusing on different socio-economic conditions and amenities as key factors influencing the price gradient. While natural amenities have more effect on the housing price gradient between cities [39,40], proximity to important urban nodes influences it within them, especially in non-monocentric cities [41] and metropolitan areas.

On the supply side, regulatory constraints are key factors affecting housing prices and the price gradient. They may significantly raise house prices in particular areas of a city [42-45], and the magnitude of this phenomenon is greater in Italy than elsewhere, due to strict rules governing the conservation of the country's building heritage, especially in historical city centers, both in metropolitan areas and in the small towns.

Most research focusing on the demand side has considered population, income, and wages as the socio-economic features influencing market demand, affecting the price gradient between and within cities, and explaining spatial segregation phenomena. For instance, Margo [46] measured the correlation between rising incomes and populations migrating from the inner city to suburban areas in post-war urbanization in the US. To our knowledge, only one noteworthy empirical study has been conducted on the Italian context [16], which demonstrated the positive correlation between income and housing prices, with a stronger effect in the city centers than in the suburbs.

The currently-available literature on immigration and property markets thus sheds little light on the situation in Italy. Even when housing prices were assessed, there was no evidence of the foreign-born population affecting the price gradient. Hence, our effort to test whether this impact really exists and, if so, to assess its magnitude. As discussed above, if there is a correlation between population and housing prices, and changes or growth in a population affect the local housing price gradient, then immigrants (as a feature of an urban population) may influence the price gradient too. To our knowledge, this is the first attempt at an empirical analysis on these issues in Italy.

\section{Data and Methods}

In this section, we present the original dataset on which our statistical assessment was conducted. All data refer to 2016. As in similar analyses $[3,6,16]$, we ran a multivariate regression to ascertain the influence of the immigrant population on the housing price gradient in 112 Italian provincial capitals. Housing price data, for both new-build and existing units, are collected by the Consulente Immobiliare, an Italian real estate journal that publishes average prices for large and middle-sized Italian cities every six months. These data are provided locally by real estate agents and compared with actual housing transactions. The prices are indicated separately for central, semi-central, and suburban areas, based on the cities' orographic structure, infrastructure availability, historic development, and localization of economic activities. This is clearly a simplification of a city's structure (especially in the case of the larger ones), but most Italian provincial capitals still retain their historical monocentric structure (for historical reasons), and this division into three parts is the most accurate of the official sources available. The reference boundary is the administrative perimeter of each city. The Consulente Immobiliare was chosen as the source of house prices too, again because it is the most accurate of the official sources available for the sample selected. In fact, the journal's data are so accurate that the Banca d'Italia (the Italian National Bank) uses them to construct its residential property price indicator [47]. We constructed the housing price gradient from the ratio between prices in the city centers and those in the suburbs. This gradient was used as the dependent variable (y), instead of the average housing prices, because it may help to reveal whether immigration is correlated with the polarization of prices within cities. It is well known that immigrant populations in cities and metropolitan areas tend to cluster in 
given neighborhoods, both in the city centers and in the fringe areas [4,48]. Spatial segregation may consequently correspond to a greater price polarization in urban residential markets [20,49]. Average house prices are only accurate in describing such phenomena for the purposes of spatial models and GIS analyses.

We considered the prices of new-build units and existing units separately for three reasons. First, most residential homes are existing units because of the high incidence of historical buildings in Italian cities. Second, the severe decline of the construction industry since 2008 has significantly reduced the new-build housing market. The number of residential construction permits dropped by $80.8 \%$ from 2005 to 2013 (Source: ANCE-Construction Companies' National Association, 2015). Third, data on building permits issued in Italy are not available by city and year, but only at regional level, so it is impossible to calculate weighted average house prices. Methodologically, it would be a mistake to use the mean of the average prices for the two submarkets, because the higher prices of new units would have an excessive influence on the mean values for a given city.

The main independent variables, i.e., the immigrant and native population data, were obtained from the Italian National Statistics Institute (ISTAT). As mentioned earlier, the foreign-born population is growing all over Italy, but is not evenly distributed. There are just 13 cities where more than $15 \%$ of the population consists of immigrants, and they are all in five regions of northern and central Italy. Only five of these 13 cities are metropolitan, while the others have a population of less than 200,000. In another 32 cities, immigrants account for $10 \%$ to $15 \%$ of the population, and 38 cities have an immigrant population between $5 \%$ and $10 \%$. Here again, most of these cities are in northern and central Italy. Cities where less than $5 \%$ of the population is foreign-born and are mostly in southern Italy (see Figure 1).

According to [1], in 2015, Italy's immigrants were from 198 countries, most of them from Central and Eastern Europe, and North Africa (especially Romania, Morocco, and Albania). Asylum-seekers account for $7 \%$ of all the immigrants, with temporary residency permits (who make up $57.2 \%$ of the total), but this group is constantly growing due to political upheaval in North Africa and the Middle East. These data are only available at the national level, so the situation cannot be analyzed at the urban level.

These data only concern the legal immigrant population and are certainly biased because there are more irregular immigrants in the south of the country. They nonetheless reflect a national trend attributable to the longstanding economic divide between north and south, with fewer job opportunities, lower wages, and worse-quality public services and infrastructure in southern Italy [50].

Accettauro et al. [4] questioned the efficacy of considering the average house prices when analyzing the impact of immigration on the residential housing market, but not enough socio-economic data are available to enable empirical analyses at the neighborhood level for Italy's provincial capitals. These data are only available at the urban level, except for for the bigger cities (and neither for the cities in their metropolitan areas). Performing the analysis on a more detailed scale-such as neighborhood level—would have obliged us to restrict the sample to the metropolitan cities, which would have been unable to give a picture of the situation in Italy as a whole.

As in the literature [51,52], to address endogeneity issues that might affect our results, we adopted other socio-economic variables at the urban level (also drawn from ISTAT data), such as the number of employees in services, retail, and tourism, the female employment rate, and the overall employment rate, which reflect the economic vitality of a city. Then, we obtained the per capita income from the Italian Ministry of Economy and Finance. We also considered other control variables measuring the role of urban structure. The per capita transportation index was retrieved from the Istituto Tagliacarne, an Italian research center whose data are also used by the national government. From the ISTAT data we obtained: the number of residential units, and the total housing unit surface area; the urban density, measured as the number of inhabitants per square kilometer; and the altitude (to control for any specific orographic condition that may affect the housing market and urban structure). 
Table 1 contains the descriptive statistics for the dataset. The housing gradient was slightly higher for new-build than for existing units, with a maximum standard deviation of $35 \%$ for the latter. The maximum value was more than twice the mean value for existing units, and just under twice the mean value for the new-build units. The three highest values were found in Naples and Rome for the new-build submarket, and in Naples and Milan for the existing units.

The simple correlation matrix in Table 2 shows the positive correlation between housing gradient and immigration, and all but 4 of the 17 variables correlated statistically with the housing gradient. Remarkably, some of the key variables considered in the literature, i.e., employment rate, and distance between a city's center and suburbs, did not correlate significantly with the housing gradient. All of the variables correlated with immigrant population, however, confirming other empirical research conducted in both Italy and the U.S.

Nevertheless, given the high probability of multicollinearity between some of the variables (as the correlation matrix demonstrates) we selected just a few that may be significant at socio-economic level for the further statistical analysis.

Table 1. Descriptive statistics.

\begin{tabular}{|c|c|c|c|c|}
\hline Variables & Mean & Standard Deviation & Minimum & Maximum \\
\hline Housing gradient (new units) & 1.88 & 0.33 & 1.11 & 3.37 \\
\hline Housing gradient (existing units) & 1.83 & 0.35 & 1.18 & 4.03 \\
\hline Population (No.) & $163,243.00$ & $318,638.00$ & $15,019.00$ & $2,864,730.00$ \\
\hline Immigrants (No.) & $17,562.70$ & $43,744.30$ & 779.00 & $365,181.00$ \\
\hline $\begin{array}{l}\text { Employees in retail and } \\
\text { tourism (No.) }\end{array}$ & $10,886.30$ & $20,096.80$ & 1051.00 & $181,310.00$ \\
\hline Employees in services (No.) & $10,536.20$ & $24,729.70$ & 723.00 & $209,855.00$ \\
\hline Female employment rate (\%) & 48.36 & 12.40 & 24.14 & 66.48 \\
\hline Employment rate & 57.46 & 10.31 & 37.05 & 72.68 \\
\hline Per capita income (euro) & $25,854.60$ & 2698.53 & $18,331.50$ & $37,309.50$ \\
\hline Urban density (pop/km²) & 1181.23 & 1364.49 & 66.31 & 8183.89 \\
\hline $\begin{array}{l}\text { Per capita public transport } \\
\text { availability rate }\end{array}$ & 81.82 & 109.45 & 3.60 & 689.20 \\
\hline $\begin{array}{l}\text { Distance between center and } \\
\text { suburbs }(\mathrm{km})\end{array}$ & 3.94 & 1.69 & 1.46 & 11.43 \\
\hline Housing unit surface area $\left(\mathrm{m}^{2}\right)$ & $6,368,710.00$ & $11,577,600.00$ & $700,865.00$ & $103,499,000.00$ \\
\hline Mean altitude ( $\mathrm{m}$ asl) & 233.00 & 234.90 & 0.91 & 1168.21 \\
\hline Housing units (No.) & $67,490.90$ & $129,880.00$ & 6529.00 & $1,137,390.00$ \\
\hline $\begin{array}{l}\text { Building density (housing units per } \\
\text { residential building) }\end{array}$ & 4.25 & 2.15 & 1.75 & 14.95 \\
\hline
\end{tabular}


Table 2. Correlations matrix.

\begin{tabular}{|c|c|c|c|c|c|c|c|c|c|c|c|c|c|c|c|}
\hline No. & Variables & (3) & (4) & (5) & (6) & (7) & (8) & (9) & (10) & (11) & (12) & (13) & (14) & (15) & (16) \\
\hline (1) & Housing gradient (new units) & $0.461 *$ & $0.402 *$ & 0.501 * & $0.515^{*}$ & -0.036 & -0.108 & $0.345^{*}$ & 0.390 * & 0.434 * & 0.054 & 0.513 * & $-0.158^{* * *}$ & 0.517 * & $0.415^{*}$ \\
\hline (2) & $\begin{array}{l}\text { Housing gradient } \\
\text { (existing units) }\end{array}$ & $0.503 *$ & $0.410 *$ & $0.483 *$ & $0.485^{*}$ & -0.112 & 0.094 & 0.290 * & $0.387 *$ & $0.400 *$ & 0.093 & 0.504 * & $-0.195^{* *}$ & 0.508 * & 0.417 * \\
\hline (3) & Log Population (No.) & 1 & $0.856^{*}$ & $0.761 *$ & $0.708^{*}$ & 0.031 & 0.026 & $0.375^{*}$ & $0.587^{*}$ & $0.617^{*}$ & $0.348^{*}$ & $0.77^{*}$ & $-0.349 *$ & $0.766^{*}$ & 0.652 * \\
\hline (4) & $\begin{array}{l}\text { Log Number of } \\
\text { immigrants (No.) }\end{array}$ & & 1 & $0.677^{*}$ & $0.643 *$ & $0.445^{*}$ & $0.449 *$ & $0.543 *$ & $0.601 *$ & $0.651 *$ & $0.192 * *$ & $0.668^{*}$ & $-0.352 *$ & $0.668^{*}$ & $0.559 *$ \\
\hline (5) & $\begin{array}{l}\text { Employees in retail and } \\
\text { tourism (No.) }\end{array}$ & & & 1 & $0.979 *$ & 0.115 & 0.105 & $0.368 *$ & $0.409 *$ & $0.647 *$ & $0.406^{*}$ & $0.995 *$ & $-0.170 * * *$ & $0.995 *$ & $0.606^{*}$ \\
\hline (6) & Employees in services (No.) & & & & 1 & 0.137 & 0.126 & 0.436 * & $0.407 *$ & 0.668 * & $0.350 *$ & 0.976 * & -0.144 & $0.981 *$ & $0.637 *$ \\
\hline (7) & Female employment rate (\%) & & & & & 1 & $0.982 *$ & $0.459 *$ & $-0.200 * *$ & $0.312 *$ & $-0.176^{* * *}$ & 0.079 & 0.039 & 0.087 & 0.098 \\
\hline$(8)$ & Employment rate & & & & & & 1 & $0.455 *$ & $0.198^{* *}$ & $0.315^{*}$ & $-0.178^{* * *}$ & 0.066 & 0.007 & 0.074 & 0.102 \\
\hline (9) & Log Per capita income (euro) & & & & & & & 1 & 0.614 * & $0.551 *$ & -0.276 * & $0.380 *$ & -0.049 & $0.385^{*}$ & $0.498^{*}$ \\
\hline (10) & $\begin{array}{l}\text { Log Urban density } \\
\left(\mathrm{pop} / \mathrm{km}^{2}\right)\end{array}$ & & & & & & & & 1 & $0.451 *$ & -0.526 * & $0.428 *$ & $-0.203^{* *}$ & $0.434^{*}$ & $0.656^{*}$ \\
\hline (11) & $\begin{array}{l}\text { Per capita public transport } \\
\text { availability rate }\end{array}$ & & & & & & & & & 1 & 0.141 & $0.621 *$ & -0.138 & $0.636^{*}$ & 0.594 \\
\hline (12) & $\begin{array}{l}\text { Distance between center and } \\
\text { suburbs }(\mathrm{km})\end{array}$ & & & & & & & & & & 1 & $0.390 *$ & -0.082 & $0.377^{*}$ & -0.070 \\
\hline (13) & Housing units surface $\left(\mathrm{m}^{2}\right)$ & & & & & & & & & & & 1 & $-0.168^{* * *}$ & $0.998 *$ & $0.62 *$ \\
\hline (14) & Mean altitude (m asl) & & & & & & & & & & & & 1 & $-0.160^{* * *}$ & -0.103 \\
\hline (15) & Housing units (No.) & & & & & & & & & & & & & 1 & $0.6393^{* *}$ \\
\hline (16) & $\begin{array}{l}\text { Building density (housing } \\
\text { units per residential building) }\end{array}$ & & & & & & & & & & & & & & 1 \\
\hline
\end{tabular}

Legend: * 99\% significance; ${ }^{* *} 95 \%$ significance; ${ }^{* * *} 90 \%$ significance. 


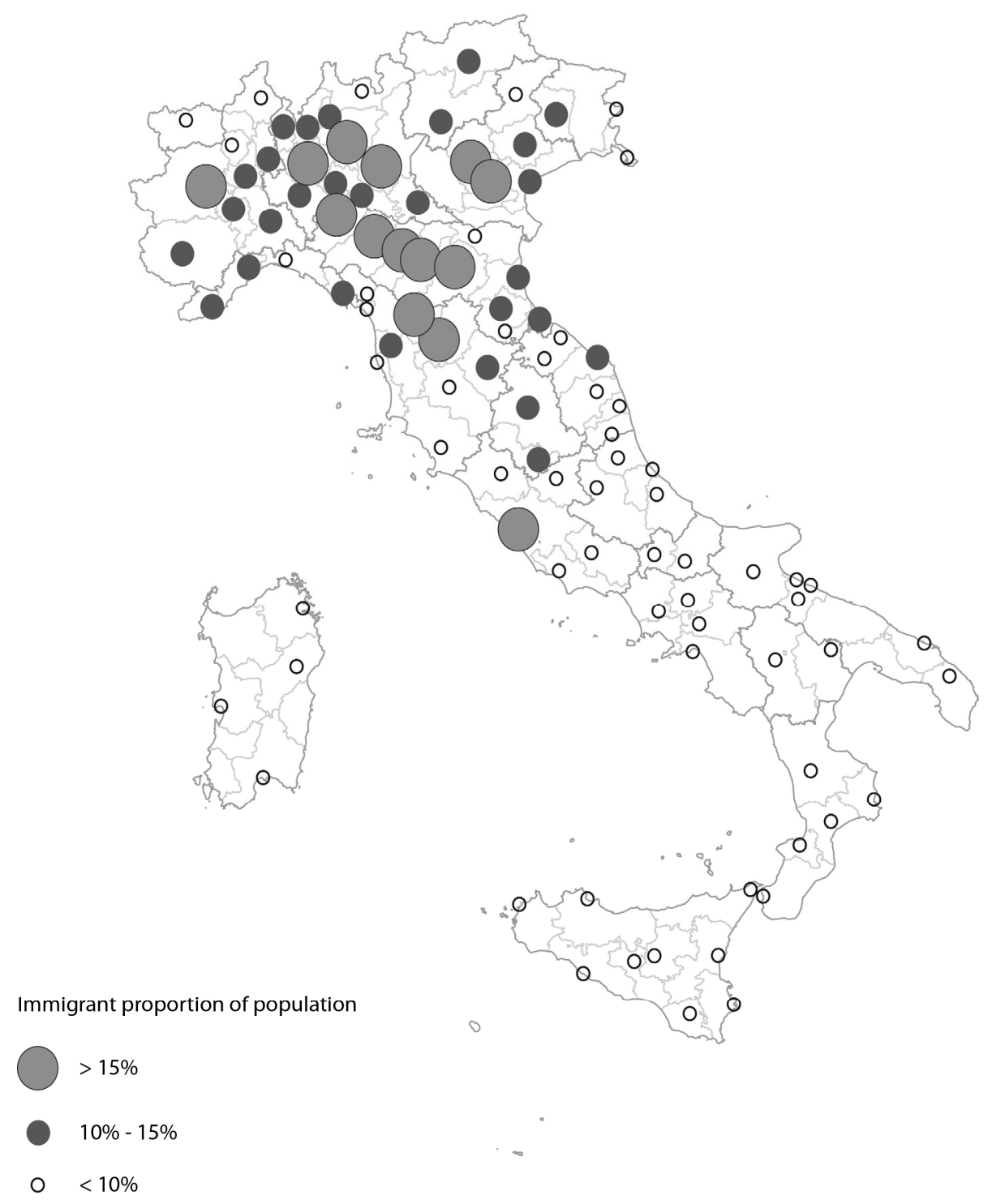

Figure 1. Proportions of immigrants in the populations of 112 provincial capitals.

\section{Results}

The first-stage estimation already demonstrated that a higher proportion of immigrants in the population corresponded to a higher housing price gradient. Then, a multivariate regression was run on the housing price gradient, for both new-build and existing units, to: (i) identify correlations between the previously-mentioned socio-economic variables; and (ii) test whether the two submarkets performed differently.

The results (Table 3) were consistent with our research hypothesis, and confirmed a strong positive correlation between immigrant populations and housing price gradients, which was slightly higher for the new-build housing submarket. The female employment rate was also significant for both submarkets, showing a strong negative correlation with the housing price gradient, and a higher incidence on the existing unit sub-market. In other words, a lower female employment rate coincided with a steeper housing price gradient. The magnitude of this correlation was greater for the existing units submarket, possibly because the market demand for existing units comes from people with a lower spending capacity, so the wages of each member of the household are more crucial to the feasibility of buying a house than for households that can afford to buy a new home. Lastly, and 
consistently with the coefficients of the other variables, per capita income had a strong influence on the housing price gradient, more or less equally affecting both submarkets.

Table 3. Estimation of housing price gradients for new-build and existing units.

\begin{tabular}{ccccc}
\hline \multirow{2}{*}{ Dependent Variable } & \multicolumn{4}{c}{ Housing Price Gradient } \\
\cline { 2 - 5 } & \multicolumn{2}{c}{ New-Build Units } & \multicolumn{2}{c}{ Existing Housing Units } \\
\hline Parameter & Coefficient & T Value & Coefficient & T Value \\
Constant & $-8.14469^{* *}$ & -2.52236 & $-6.62062^{*}$ & -1.94131 \\
Female employment rate & $-0.0091824^{*}$ & -3.5976 & $-0.0120402 *$ & -4.54879 \\
(LOG) Immigrant population & $0.265134^{*}$ & 3.93888 & $0.14933^{*}$ & 4.82837 \\
(LOG) Per capita income & $2.14071^{*}$ & 2.80249 & $0.757284^{*}$ & 2.16321 \\
No. & - & 112 & - & 112 \\
R $^{2}$ Adj. & - & $25.13 \%$ & - & $29.00 \%$ \\
\hline
\end{tabular}

* $99 \%$ significance; $* * 95 \%$ significance.

The results reached $99 \%$ and $95 \%$ statistical significance, and the adequacy of the model was around $25 \%$ for new-build units, and nearly $30 \%$ for existing housing units. The VIF (variance inflation factor) and VCE (covariance matrix of the estimators) also confirmed that there was no multicollinearity between the variables tested in the multivariate regression (See Table 4).

Table 4. Estimation of the variance inflation factor.

\begin{tabular}{ccc}
\hline \multirow{2}{*}{ Variables } & \multicolumn{2}{c}{ Housing Price Gradient } \\
\cline { 2 - 3 } & VIF & $\mathbf{1 / V I F}$ \\
\hline Female employment rate & 1.36 & 0.735242 \\
(LOG) Immigrant population & 1.52 & 0.656559 \\
(LOG) Per capita income & 1.55 & 0.645681 \\
Mean VIF & 1.48 & - \\
\hline
\end{tabular}

Given the marked diversity of the phenomena affecting house prices, these results are very robust. They confirm the relationship between the price gradient and the proportion of immigrants in the population for both submarkets. Our results are consistent with the existing literature. The positive correlation between per capita income and housing price gradient is greater for the new residential submarket than forexisting units, confirming that the existing units submarket is flat in Italy (especially since the 2008 recession), while new-build units have become a highly-segregated niche market. The negative correlation between the female employment rate and the housing price gradient demonstrates that a higher household income contributes more to reducing the housing price gradient for existing units than for new homes.

\subsection{Immigration and the National Divide}

It is well-known that Italy has a longstanding socio-economic divide between north and south, which the economic recession has exacerbated. In addition, illegal immigrant flows arrive by sea from North Africa, consequently reaching Southern Italy, and giving rise to social degradation, housing poverty, and spatial segregation. Even the legally resident immigrant population tends to be less skilled in the south than in the north of the country, and is employed mainly in agriculture rather than in manufacturing.

If immigrants' social segregation is more severe in southern Italy, the housing price gradient should be more strongly affected by the proportion of immigrants in the population. So, after measuring the phenomenon at national level, we ran further statistical analyses after clustering our data geographically to see whether the correlation between the housing price gradient and the 
immigrant population varies from north to south. The vast majority of the housing market consists of existing units, especially in Southern Italy, so we only considered this submarket.

Although our results are consistent with those of our previous overall assessment, a few differences emerged (see Table 5). Here again, we performed the VIF test for multicollinearity (Table 6). In southern Italy, not all of the socio-economic variables analyzed showed a statistically significant correlation with the housing price gradient. To be specific, the correlation with per capita income was not statistically significant, while for per capita public transport availability rate it was. This latter variable was not relevant on a national scale, but proved significant for southern Italy. This finding is consistent with the literature, which has clarified the influence of public transport availability rates on spatial segregation, which becomes even more important in the context of racial segregation $[27,53]$.

Table 5. Estimation of the housing price gradient for existing housing units in northern versus southern Italy.

\begin{tabular}{lcccc}
\hline $\begin{array}{c}\text { Dependent Variable: Existing Unit Price } \\
\text { Gradient (Y) }\end{array}$ & \multicolumn{2}{c}{ North of Italy } & \multicolumn{2}{c}{ South of Italy } \\
\hline \multicolumn{1}{c}{ Independent Variables } & Coefficient & t-Value & Coefficient & t-Value \\
\hline Constant & $-8.63352 * *$ & -2.30376 & $1.20034^{* *}$ & 0.0200 \\
Female employment rate & $-0.0254863 * *$ & -2.37462 & $-0.0122257^{* *}$ & -2.64079 \\
(LOG) Immigrant population & $0.237165^{* *}$ & 2.63309 & $0.271045^{* *}$ & 2.01532 \\
(LOG) Per capita income & $2.46858^{*}$ & 2.79152 & - & - \\
Per capita public transport availability rate & - & - & $0.00222482 * *$ & 2.30514 \\
No. & - & 112 & - & 112 \\
$\mathrm{R}^{2}$ Adj. & - & $29.26 \%$ & - & $36.37 \%$ \\
\hline
\end{tabular}

Table 6. Estimation of the variance inflation factor.

\begin{tabular}{ccccc}
\hline \multirow{2}{*}{ Variables } & \multicolumn{2}{c}{ Housing Price Gradient (North of Italy) } & \multicolumn{2}{c}{ Housing Price Gradient (South of Italy) } \\
\cline { 2 - 5 } & VIF & $\mathbf{1 / V I F}$ & VIF & $\mathbf{1 / V I F}$ \\
\hline Female employment rate & 1.04 & 0.965004 & 1.14 & 0.448832 \\
(LOG) Immigrant population & 1.22 & 0.817850 & 2.04 & 0.491043 \\
(LOG) Per capita income & 1.23 & 0.810250 & 2.23 & 0.877593 \\
Mean VIF & 1.16 & - & 1.80 & - \\
\hline
\end{tabular}

This result may also be explained by the marked differences in the availability of public transport in southern Italy from one region to another, whereas in the north of the country the public services are more homogeneous-and consequently less relevant in explaining housing price gradients.

Our results also confirm a higher incidence of the immigrant population on the housing price gradient in southern than in northern Italy, and a lower incidence of the female employment rate. The north of the country also has more women in employment in absolute terms, with a statistically significant difference between north and south.

\subsection{Immigration and Urban Density}

As already mentioned, Italy's provincial capitals are not homogeneous in terms of population or urban and build density, so we ran a further regression step after dividing the sample into two clusters by density, considering population density (inhabitants per square kilometer), adopting a threshold of 1500 inhabitants per $\mathrm{km}^{2}$. The higher-density group included 42 cities, while the other 70 were less dense. The two groups were evenly distributed around the country.

The multivariate regression for the denser cities confirmed our previous results (Tables 7 and 8), apart from a higher adjusted $\mathrm{R}^{2}$ above $40 \%$, while the less dense cities seemed to behave differently and the multivariate regression did not generate satisfactory results. 
Table 7. Estimation of the housing price gradient for existing units in higher-density Italian provincial capitals (over $1500 \mathrm{pop} / \mathrm{km}^{2}$ ).

\begin{tabular}{ccc}
\hline Dependent Variable: Existing Unit Price Gradient (Y) & \multicolumn{2}{c}{ Denser Provincial Capitals } \\
\hline Independent Variables & Coefficient & t-Value \\
\hline Constant & $-17.2515^{* *}$ & -2.56402 \\
Female employment rate & $-0.0207327^{*}$ & -3.97491 \\
(LOG) Immigrant population & $0.436721^{*}$ & 3.63834 \\
(LOG) Per capita income & $4.14741^{*}$ & 2.66801 \\
Per capita public transport availability rate & - & - \\
No. & - & 112 \\
$\mathrm{R}^{2}$ Adj. & - & $40.63 \%$ \\
\hline
\end{tabular}

* 99\% significance; ** 95\% significance.

Table 8. Estimation of the variance inflation factor.

\begin{tabular}{ccc}
\hline \multirow{2}{*}{ Variables } & \multicolumn{2}{c}{ Housing Price Gradient (Denser Provincial Capitals) } \\
\cline { 2 - 3 } & VIF & 1/VIF \\
\hline Female employment rate & 1.19 & 0.837971 \\
(LOG) Immigrant population & 1.14 & 0.880138 \\
(LOG) Per capita income & 1.22 & 0.820171 \\
Mean VIF & 1.18 & - \\
\hline
\end{tabular}

This different result may have three not mutually exclusive explanations. First, the sample may be too small to produce conclusive results, though this seems unlikely given the robustness of the results for the clusters of cities in the north and south. Second, the residential market may be less affected by immigration in the less dense provincial capitals. This seems quite likely since just 20 cities in the sample have an immigrant population accounting for more than $10 \%$ of the total. This possible explanation should be considered with caution, however, because the other socio-economic variables do not seem sufficient to explain the residential housing price gradient. Lastly, although urban population density is a significant factor for interpreting the Italian housing market $[13,14]$, clustering cities by density may not conclusively elucidate the relationship between housing price gradient and immigration phenomena.

\section{Conclusions}

Legal and illegal immigration is on the rise in Italy and elsewhere in Southern Europe, especially since the Arab Spring, and the ensuing political fragility in the Middle East. The influx of immigrants to Europe began in the mid-1990s, however, and Italy's cities already have a well-established immigrant urban population.

The aim of this article was to examine the impact of immigration on the residential market's price gradient. Numerous previous studies examined the impact of immigration on housing prices, at the city and neighborhood level, but none considered how this phenomenon affects the housing price gradient. This factor is significant because it may also be a proxy of the social and economic divide, and even of segregation within and between cities. After reviewing the existing literature on the subject, we ran statistical analyses on an original dataset concerning 112 provincial capitals. Our results demonstrate a positive correlation between the immigrant population and the housing price gradient at national level, for both new-build and existing housing units. They also show the importance of other variables identified in the literature, such as per capita income and the female employment rate. When we analyzed our dataset separately for the north and south of Italy (which have traditionally had quite different economic and social conditions), our national-scale results were confirmed, but some relevant differences emerged regarding the housing price gradient. 
Even if neoclassical economic theory assumes that land is more valuable in city centers due to greater accessibility, and more amenities and employment opportunities (see, among others, [34-38]), other factors may affect this phenomenon. In the present case, we examined how a major evolution in Italy's demographics, with an increasing proportion of immigrants in its urban populations, might affect the housing price gradient, in terms of both sign and magnitude. The statistical correlation between housing price gradient and immigrant population may not alone suffice to explain an increase in social and economic segregation at the urban level. On the other hand, this is another proof of the potential increasing of urban divide between the growing proportion of the population with low incomes and wages (who tend to live in the suburbs), and the town's wealthier residents.

While substantial research has been done on income and social segregation in Italy, the present study is the first attempt to measure the incidence of immigration on the housing market from a nationwide perspective. Our analysis also showed that the trend of the housing market in Italy, on a national scale at least, is still consistent with the well-known urban economic behavior of the monocentric city model, even though Italian cities large and small have been sprawling more and more in the last thirty years. Our findings should prompt further research on this topic. To refine the analysis, more tests should be conducted at metropolitan level in Italy's larger cities. The behavior of the residential market in the less dense cities also deserves a more in-depth analysis, expanding the sample to neighboring towns to take into account potentially multicentric phenomena affecting the housing market that national-scale analyses are unable to identify. Other investigations could be conducted on the role of immigration in the improvement or deterioration of urban amenities, at both the city and neighborhood levels. This would be more important for southern Italian cities, where historical centers are still partly inhabited by the most fragile part of the population. Lastly, a time series data analysis might help us to predict future trends of the housing market in Italy.

Author Contributions: Valentina Antoniucci and Giuliano Marella conceived and designed the statistical models and they analyzed the results in equal parts; Valentina Antoniucci collected the dataset, developed the literature review.

Conflicts of Interest: The authors declare no conflict of interest.

\section{References}

1. Caritas e Migrantes. XXV Rapporto Immigrazione 2015. La cultura dell'incontro. Sintesi. Available online: http:/ / www.caritas.it/caritasitaliana/allegati/6472/Sintesi_OK\%20(1).pdf (accessed on 10 July 2017).

2. Boeri, T.; de Philippis, M.; Patacchini, E.; Pellizzari, M. Moving to Segregation: Evidence from 8 Italian Cities. IZA Discussion Paper 2012, 6834, 1-63.

3. Chiodelli, F.; Moroni, S. Planning, pluralism and religious diversity: Critically reconsidering the spatial regulation of mosques in Italy starting from a much debated law in the Lombardy region. Cities 2017, 62, 62-70. [CrossRef]

4. Accetturo, A.; Manaresi, F.; Mocetti, S.; Olivieri, E. Don't stand so close to me: The urban impact of immigration. Reg. Sci. Urban Econ. 2014, 45, 45-56. [CrossRef]

5. Mocetti, S.; Porello, C. How does immigration affect native internal mobility? New evidence from Italy. Reg. Sci. Urban Econ. 2010, 40, 427-439. [CrossRef]

6. Saiz, A. Room in the kitchen for the melting pot: Immigration and rental prices. Rev. Econ. Stat. 2003, 85, 502-521. [CrossRef]

7. Goodman, A.C. Central cities and housing supply: Growth and decline in US cities. J. Hous. Econ. 2005, 14, 315-335. [CrossRef]

8. Glaeser, E.L.; Resseger, M.; Tobio, K. Inequality in cities. J. Reg. Sci. 2009, 49, 617-646. [CrossRef]

9. Brücker, H.; Jahn, E.J. Migration and Wage-setting: Reassessing the Labor Market Effects of Migration. Scand. J. Econ. 2011, 113, 286-317. [CrossRef]

10. Clark, K.; Drinkwater, S. The labour-market performance of recent migrants. Oxf. Rev. Econ. Policy 2008, 24, 495-516. [CrossRef]

11. Cristaldi, F. Multiethnic Rome: Toward a residential segregation? GeoJournal 2002, 58, 81-90. [CrossRef] 
12. Ley, D.; Tutchener, J.; Cunningham, G. Immigration, polarization, or gentrification? Accounting for changing house prices and dwelling values in gateway cities. Urban Geogr. 2002, 23, 703-727. [CrossRef]

13. Antoniucci, V.; Marella, G. Small town resilience: Housing market crisis and urban density in Italy. Land Use Policy 2016, 59, 580-588. [CrossRef]

14. Antoniucci, V.; Marella, G. Is social polarisation related to urban density? Evidence from the Italian housing market. Lands. Urban Plan. 2017, in press. [CrossRef]

15. Dong, H.; Hansz, A.J. The geography of the recent economic crisis: The role of urban form. Hous. Policy Debate 2016, 26, 150-171. [CrossRef]

16. Manzoli, E.; Mocetti, S. I prezzi delle case e il gradiente centro-periferia: Evidenze dalle città italiane. Questioni di Economia e Finanza settembre 2016, 348, 4-36.

17. Gonzalez, L.; Ortega, F. Immigration and housing booms: Evidence from spain. J. Reg. Sci. 2013, 53, 37-59. [CrossRef]

18. Benabou, R.; Ok, E. Mobility as Progressivity: Ranking Income Processes According to Equality of Opportunity. Natl. Bur. Econ. Res. 2001, 8431. [CrossRef]

19. Baker, E.; Bentley, R.; Lester, L.; Beer, A. Housing affordability and residential mobility as drivers of locational inequality. Appl. Geogr. 2016, 72, 65-75. [CrossRef]

20. Arbaci, S.; Malheiros, J. De-segregation, peripheralisation and the social exclusion of immigrants: Southern European cities in the 1990s. J. Ethn. Migr. Stud. 2010, 36, 227-255. [CrossRef]

21. Arapoglou, V.P.; Sayas, J. New Facets of Urban Segregation in Southern Europe. Eur. Urban Reg. Stud. 2009, 16, 345-362. [CrossRef]

22. Tammaru, T.; Strömgren, M.; van Ham, M.; Danzer, A. M Relations between residential and workplace segregation among newly arrived immigrant men and women. Cities 2016, 59, 131-138. [CrossRef]

23. Bolt, G.; van Kempen, R.; van Ham, M. Minority Ethnic Groups in the Dutch Housing Market: Spatial Segregation, Relocation Dynamics and Housing Policy. Urban Stud. 2008, 45, 1359-1384. [CrossRef]

24. Ireland, P. Comparing responses to ethnic segregation in urban Europe. Urban Stud. 2008, 45, 1333-1358. [CrossRef]

25. Glaeser, E.L.; Kahn, M.E. Sprawl and urban growth. In Handbook of Regional and Urban Economics; Henderson, J.V., Thiesse, J.F., Eds.; Elsevier: North Holland, The Netherlands, 2004; Volume 4.

26. Wheeler, C.H. Urban Decentralization and Income Inequality: Is Sprawl Associated with Rising Income Segregation Across Neighborhoods? Fed. Reserv. Bank St. Louis Reg. Econ. Dev. 2008, 4, 41-57. [CrossRef]

27. Ewing, R.; Hamidi, S.; Grace, J.B.; Wei, Y.D. Does urban sprawl hold down upward mobility? Landsc. Urban Plan. 2016, 148, 80-88. [CrossRef]

28. Saiz, A. Immigration and housing rents in American cities. J. Urban Econ. 2007, 61, 345-371. [CrossRef]

29. Ley, D.; Tutchener, J. Immigration, globalisation and house prices in Canada's gateway cities. Hous. Stud. 2001, 16, 199-223. [CrossRef]

30. Kashnitsky, I.; Gunko, M. Spatial variation of in-migration to Moscow: Testing the effect of housing market. Cities 2016, 59, 30-39. [CrossRef]

31. Degen, K.; Fischer, A.M. Immigration and Swiss House Prices (November 2009). CEPR Discussion Paper. No. DP7583. Available online: https:/ / ssrn.com/abstract=1533188 (accessed on 10 July 2017).

32. Sà, F. Immigration and Housing prices in UK. Econ. J. 2014, 125, 1393-1424. [CrossRef]

33. Mussa, A.; Nwaogu, U.G.; Pozo, S. Immigration and housing: A spatial econometric analysis. J. Hous. Econ. 2017, 35, 13-25. [CrossRef]

34. Alonso, W. Location and Land Use: Towards a General Theory of Land Rends; Harvard University Press: Cambridge, MA, USA, 1964.

35. Mills, E.S. An aggregative model of Resource allocation in a Metropolitan Area. Am. Econ. Rev. 1967, 57, 197-210.

36. Muth, R.F. Cities and Housing. In The Spatial Pattern of Urban Residential Land Use; University of Chicago Press: Chicago, IL, USA, 1969.

37. DiPasquale, D.; Wheaton, C.W. Housing market dynamics and the future of housing prices. J. Urban Econ. 1994, 35, 1-27. [CrossRef]

38. Capozza, D.; Hendershott, P.; Mack, C.; Mayer, C.J. Determinants of Real House Price Dynamics. NBER Work. Pap. 2002. [CrossRef] 
39. Gong, Y.; Boelhouwer, P.; de Haan, J. Interurban house price gradient: Effect of urban hierarchy distance on house prices. Urban Stud. 2015, 53, 3317-3335. [CrossRef]

40. Rappaport, M.J. Moving to nice weather. Reg. Sci. Urban Econ. 1997, 37, 375-398. [CrossRef]

41. Dubin, R.A.; Sung, C.-H. Spatial variation in the Price of Housing: Rent gradients in non-monocentric cities. Urban Stud. 1987, 24, 193-204. [CrossRef]

42. Canesi, R.; Antoniucci, V.; Marella, G. Impact of socio-economic variables on property construction cost: Evidence from Italy. Int. J. Appl. Bus. Econ. Res. 2016, 14, 9407-9420.

43. Antoniucci, V.; Marella, G. Torri incompiute: i costi di produzione della rigenerazione urbana. Sci. Reg. 2014, 13, 117-124. [CrossRef]

44. Glaeser, E.L. The impact of zoning on housing affordability. J. Urban Econ. 2002, 31, 301-310. [CrossRef]

45. Glaeser, E.L.; Gyourko, J.; Saks, R. Why Is Manhattan So Expensive? Regulation and the Rise in Housing Prices*. J. Law Econ. 2005, 48, 331-369. [CrossRef]

46. Margo, R.A. Explaining the postwar suburbanization of population in the United States: The role of income. J. Urban Econ. 1992, 31, 301-310. [CrossRef]

47. Muzzicato, S.; Sabbatini, R.; Zollino, F. Prices of residential property in Italy: Constructing a new indicator. Questioni di Economia e Finanza, 2008, 17. [CrossRef]

48. Waddell, P.; Berry, J.L.; Hoch, I. Housing Price gradients: The intersection of Space and Built form. Geogr. Anal. 1993, 25, 5-19. [CrossRef]

49. Arnott, R. Economic theory and the Spatial Mismatch Hypotesis. Urban Stud. 1998, 35, 1171-1185. [CrossRef]

50. Felice, E. Regional value added in Italy, 1891-2001, and the foundation of a long-term picture. Econ. Hist. Rev. 2011, 64, 929-950. [CrossRef]

51. Del Giudice, V.; De Paola, P.; Forte, F. Using Genetic Algorithms for Real Estate Appraisals. Buildings 2017, 7, 31. [CrossRef]

52. Del Giudice, V.; Manganelli, B.; De Paola, F. Hedonic analysis of housing sales prices with semiparametric methods. Int. J. Agric. Environ. Inf. Syst. 2017, 8, 65-77. [CrossRef]

53. Gobillon, L.; Selod, H.; Zenou, Y. The Mechanisms of Spatial Mismatch. Urban Stud. 2007, 44, $2401-2427$. [CrossRef]

(C) 2017 by the authors. Licensee MDPI, Basel, Switzerland. This article is an open access article distributed under the terms and conditions of the Creative Commons Attribution (CC BY) license (http://creativecommons.org/licenses/by/4.0/). 